\title{
Estimating financing gaps in rice production in Southwestern Nigeria
}

\author{
T. O. Ojo $\mathrm{O}^{1,4^{*}} \mathbb{B}$, A. A. Ogundeji ${ }^{2}$, S. C. Babu ${ }^{3}$ and T. Alimi ${ }^{4}$
}

\author{
${ }^{*}$ Correspondence: \\ ojotemitope70@yahoo.com \\ 1 Disaster Management \\ Training and Education \\ Centre for Africa, University \\ of the Free State, \\ Bloemfontein, South Africa \\ Full list of author information \\ is available at the end of the \\ article
}

\begin{abstract}
This study analysed the financing gaps relative to production frontier of rice farmers in Southwestern Nigeria. A multistage sampling technique was used to collect crosssectional data from 360 rice farmers selected from three states in the region. A CobbDouglas stochastic frontier and an adapted form of Harrod-Domar (HD) growth model was employed to determine the financing gap required the farmers to be at the frontier level. The empirical results of the frontier model show that quantity of labour, quantity of rice as planting material and herbicides were statistically significant in explaining the variations in the efficiency of rice production in Nigeria. However, age, gender, farming experience, household size, access to credit, access to information, adoption of improved variety and location of rice farmers as sources of technical inefficiencies. As revealed by the result of the HD growth model, the average amount of credit per season that farmers had access to was, 38,630.56 naira ( while the mean financing in the form of credit required to produce at the frontier level was 193,626.50, showing a financing shortfall of about $80 \%$. As unravelled by the result of the study, it can thus be concluded that technical efficiency of rice farmers can be improved by ameliorating access to timely credit and agricultural information for improving rice productivity. These findings suggest that filling the financing gap of smallholder rice farmers will improve rice productivity in Nigeria. The study, therefore, recommends that strengthening the existing technology by building farmers' capacity on farm management practices would be the surest means of improving rice productivity growth in Nigeria. This would not only contribute to the intensification of rice production in Nigeria to meet its increasing rice demand, but also improve rice farmers' productivity and their households'incomes.
\end{abstract}

Keywords: Financing gaps, Stochastic frontier, Harold-Domar growth model

\section{Introduction}

Rice is one of the most valuable cereal crops cultivated and consumed all over the world. It is a staple food in several African counties, Nigeria as an example and constitutes a large portion of the diet on a regular basis (Lu et al. 2018). Rice is cultivated in mostly all agro-ecological zones in Nigeria but on a relatively small scale. As asserted by FAO (2015), Nigeria is the continent's leading consumer of rice, one of the largest producers of rice in Africa and simultaneously one of the largest rice importers in the world. Rice is an important food security crop, it is an essential cash crop for it is 
mainly small-scale producers who commonly sell $80 \%$ of total production and consume only $20 \%$.

Farm productivity of staple crops, in developing nations such as Nigeria, is low due to traditional methods of farming, poor irrigation facilities, land fragmentation, the impact of climate change, misuse of modern agricultural technology, and less availability of credit (Chandio et al. 2017). Among the staple crops, rice has risen to a position of eminence in Nigeria. Rice is the most important staple food for about half of the human race (Akinbode 2013). According to USDA (2016), the annual consumption of rice in Nigeria was about 5 million MT while quantity supplied was 2.7 million MT, with a demand-supply gap of about 2.3 million MT, which is today filled in by importation (Obih and Baiyegunhi 2017). Nigeria still ranks third with Iraq (after the Philippines and China) in the group of major rice importing countries in the world.

Rice (Oryza spp. L.), a grain cereal, is an important staple food for the world's human population, providing more than $20 \%$ of the calories consumed worldwide (Kenmore 2003). It has the second highest production worldwide, after maize (Mohanty et al. 2013). Rice is an important crop that has allured several studies in Nigeria. Some studies had focused on adoption of improved rice variety (Awotide et al. 2013); consumption and marketing of rice (Obih and Baiyegunhi 2018) whilst others focused on resource use efficiency (Goni et al. 2007; Ogundari 2008) and technical efficiency (Ogundele and Okoruwa 2006). A review of studies related to agricultural producers' efficiency shows there is a large body of literature dealing with farm-level technical efficiency.

According to Ogundele and Okoruwa (2006), efficiency measurement is imperative as success indicator and performance measure by which production units are evaluated, as well as an avenue to identify sources of production inefficiency. According to Fakayode (2009) where inadequate funds was considered as the greatest challenge limiting rice production, flooding was also considered as a challenge limiting rice production especially the upland smallholder rice farmers as found in Southwestern, Nigeria. As argued by Guirkinger and Boucher (2008), the significant adverse effects of credit constraints on farm productivity of smallholder farmers in the rural areas of developing countries such as Nigeria are alarming. Olomola and Gyimah-Brempong (2014) attributed the low productivity in the agricultural sector to the subsistence nature of agriculture and lack of credit availability.

However, the influences of financing on technical efficiency of smallholder rice farmers have been given very little attention, which accordingly is the focus of this study. This study primarily focuses on assessing the financing gaps relative to production frontier of smallholder rice farmers in Southwestern Nigeria. It also investigates the socio-demographic factors that influence inefficiency in agricultural production among rice farmers. As a caveat for this study, the technical efficiency of rice smallholder rice farmers is estimated and an adapted form of the Harold-Domar (HD) growth model was employed to estimate the financing (credit) gap of smallholder rice farmers in Southwestern Nigeria. The information on the financing (credit) gap can indicate to policymakers on how the intensification of rice production in Nigeria to 
meet its increasing rice demand, and also rice farmers' productivity and welfare can be improved.

\section{Empirical framework}

\subsection{Harrod-Domar (HD) model and financing gap measurement}

As posited by Easterly (1999), and recently applied by Tang et al. (2018), Bermejo Carbonell and Werner (2018), van der Merwe and Dodd (2019), Harrod-Domar growth model has been employed in international financing institutions (IFIs). Chenery and Strout (1966) gave the definitive statement of the Financing Gap model in their Two-Gap model that aid will "fill the temporary gap between investment ability and saving ability". The usual ICOR formulation determines investment requirements for a given growth target.

Easterly (1999) noted that the model has two important features viz. (A) investment requirements to achieve a given growth rate are proportional to the growth rate by a constant known as the Incremental Capital Output Ratio (ICOR) and (B) aid requirements are given by the "Financing Gap" between the investment requirements and the financing available from the sum of private financing and domestic saving. Moreover, he referred to this model as "Financing Gap Model" for short, because, according to him, its most important use is to determine financing shortfalls. $\mathrm{He}$ further noted that (A) and (B) imply the following testable assumptions: (1) aid will go into investment one for one, and (2) there will be a fixed linear relationship between growth and investment in the short run. The constant of proportionality is one over the ICOR.

The shortcomings of the Harrod-Domar approach are well noted in the study of Hussain (2000). These, he stated, centre on two closely related problems. The first is the inaccuracy of estimating the resource gap to achieve a target rate of growth and the second is the failure of the basic Harrod-Domar relationship to predict growth rates. With regard to the former, he noted that if the economy is working below capacity, which is typical in most developing countries such as Nigeria, the true value of the ICOR cannot be computed with any degree of precision, and definitely not with the precision suggested by the equations. Also, he noted that the Harrod-Domar approach assumes that all additional growth in income is attributed to the increments of capital. The approach overstates the productivity of capital and understates the ICOR based on the fact that other factors contribute to growth.

However, Geda et al. (2009) observed that there are a number of considerations that still make the Harrod-Domar (HD) framework attractive for policy, which includes: (1) it deals with short-run planning problems, while most growth models that have theoretical appeal and some degree of sophistication deal with long-run growth. They noted that this distinction is very important in application because it is about an economy reaching its equilibrium or steady state over a certain period of time, or to be specific, zero per capita growth or GDP growing at the rate of population growth. (2) The lack of alternative models that can fit the needs of policymakers and practitioners like development banks, especially in dealing with short to mediumterm financing needs. (3) The HD approach provides a useful benchmark-a firstorder approximation to the complicated task of estimating financing needs for 
development. It allows a check on consistency across the macroeconomic balances as well as sectoral investment programmes. They finally concluded that HD may continue to be relevant when time and resources are limited.

In analysing the empirical validity of HD in the African context, Easterly (1999) found no empirical basis to support the 44 predictions of the HD in over 138 countries for the 1950-1992 period. In the same vein, Bermejo Carbonell and Werner (2018) also found that the Spanish EU and euro entry have had no positive effect on growth. The findings call for a fundamental rethinking of methodology in economics. However, Geda et al. (2009) were unable to replicate Easterly's findings. Setting aside issues of model specification and others, they attempted to re-examine these relationships for a sample of 12 African countries and their results actually suggested a strong support for HD predictions with the exception of two countries. They found significant relationships between growth and investment for the 10 countries when a constant is added in the OLS regression. They noted that this is because the HD model assumes no constant term in the relationship between growth and investment (proportionality) and that once they imposed a zero constant on the regressions, it turned out that all countries exhibit a strong and positive short-term relationship between investment and growth.

They also found the relationship between aid and investment to be positive, and in most cases, significant. Although they agreed with the argument that HD ignores diminishing returns to aid, they however stated that the existence of diminishing returns implies that the straightforward HD projections will underestimate the actual resource requirements. In summary, Geda et al. (2009) stated that the African Development Bank (AfDB), as well as other institutions, continue to use various methodologies to estimate resource requirements for developing countries. They noted that any of these methodologies has its own limitations in relation to empirical application to countryspecific and context-specific circumstances. However, they affirmed that estimates generated from simple models like the HD turn out to be very consistent with estimates generated by more sophisticated methodologies.

\subsection{Conceptual and analytical frameworks}

For this study, a stochastic frontier analysis (SFA) framework was used to assess the technical efficiency of rice production in the study area. The basic stochastic frontier production function of rice production can be expressed as;

$$
Y_{i}=f\left(X_{i} ; \beta\right) \exp \left(v_{i}-u_{i}\right)
$$

where $Y_{i}$ denotes the quantity of rice produced by $i$ th farm $(i=1,2, \ldots N), X_{i}$ is a vector of production inputs of the $i$ th farm, and $\beta$ is a $(k x 1)$ vector of unknown parameters to be estimated. $v_{i}$ is a stochastic noise distributed symmetrically with mean zero and unknown variance $N\left(0, \sigma_{\mathrm{V}}^{2}\right)$ (Aigner et al. 1977). $u_{i}$ are systematic and non-negative random variables which are responsible for farmers technical inefficiency in production and are obtained by truncation (at zero) of normal distribution with mean $z_{i} \dot{\partial}$, and variance $\sigma^{2} . z_{i}$ is a vector of covariates explaining technical inefficiency associated with farm production and, $\delta$ is a vector of unknown parameters (Battese and Coelli 1995). 
In line with the frontier production function as specified in Eq. (1), the study define technical efficiency of the $i$ th rice farm as the ratio of the observed rice mean output, given the values of production inputs $\left(X_{i}\right)$ and its assumed technical inefficiency effects $\left(u_{i}\right)$, to corresponding potential output if there was non-existence of technical inefficiency $\left(u_{i}=0\right)$ in rice production. The technical efficiency of a $i$ th farm can, therefore, be expressed as:

$$
\mathrm{TE}_{i}=\frac{f\left(Y_{i} / u_{1}, X_{i}\right)}{f\left(Y_{i} / u=0, X_{i}\right)}=\exp \left(-v_{i}\right)
$$

where $\mathrm{TE}_{i}$ indicates technical efficiency score which is constrained within the interval $(0,1)$. The value of 1 indicates a fully technically efficient farm and the value of 0 implies a fully technically inefficient farm. Following the single stage approach proposed by Caudill and Ford (1993), the study parameterized the variance of the pre-truncated of the inefficiency error term $u_{i}$. This is to explore how socioeconomic and policy variables influence rice farmers' performance (Kumbahkar and Lovell 2000). The inefficiency effect $\left(u_{i}\right)$ can be specified as:

$$
u_{i}=z_{i} \delta+\theta_{i}
$$

where $z_{i}$ is $(m x 1)$ vector exogenous variables explaining rice farmers' technical inefficiency, such as age, farming experience, off-farm income, household size, membership in farmers' association), $\delta$ is (1xm) vector of parameters to be estimated, and $\theta_{i}$ is an error term of the inefficiency effect.

The Cobb-Douglas production function model used to represent the production of rice is specified as

$$
\ln Q_{i}=\ln \beta_{0}+\sum_{j=1}^{5} \beta_{i} \ln Z_{i}+\left(v_{i}-u_{i}\right),
$$

where $Q_{i}$ represents value of rice output, $Z_{i}$ represents the conventional inputs usually used in rice production namely, quantity of labour used, farm size, insecticides, herbicides and quantity of seeds planted.

For this study, four main hypotheses were tested, viz; (i). There is no inefficiency effect in rice production; (ii) the coefficients of the square values and the interaction terms in translog have zero values; (iii) exogenous factors are not responsible for the inefficiency term $\left(u_{i}\right)$, and (iv) there is no heteroscedasticity in both the stochastic $\left(v_{i}\right)$ and inefficiency error terms $\left(u_{i}\right)$. The results of the four hypotheses were tested using the generalized likelihood-ratio test statistic specified as:

$$
L R(\Omega)=-2\left[\left\{\ln L\left(H_{0}\right)\right\}-\left\{\ln L\left(H_{1}\right)\right\}\right],
$$

where $L\left(H_{0}\right)$ and $L\left(H_{1}\right)$ represent the likelihood functions under null and alternative hypotheses, respectively. Following Coelli (1995), if the null hypothesis is rejected, then the test statistic $(\lambda)$ has a Chi-square distribution of the degree of freedom defined as the difference between the estimated parameters under $\left(H_{1}\right)$ and $\left(H_{0}\right)$. However, if the null hypothesis is accepted, then the asymptotic distribution involves a mixed Chi-square distribution. The results of the four null hypotheses tested are presented in Table 2. 


\subsection{Harold-Domar growth model}

According to Geda et al. (2009) regarding the continuous relevance and usefulness of the HD model in estimating financing gap, this study employed an adapted form of the HD model to estimate the financing (credit) gap of smallholder rice farmers in Southwestern Nigeria. However, in order to place all the producers on a desirable efficiency level (growth rate) and cater for the issue of efficient use of investment, the growth rate in the HD model is substituted with the production frontier. Thus, this study is based on the assumption that: credit amounts required by rice farmers to produce at the frontier level are directly proportional to the production frontier by a constant known as the Incremental Capital Output Ratio (ICOR). In the same vein, it is assumed that credit (finance) requirements of the farmers are given by the "Financing Gap" between the credit amount required to produce at the frontier level and the finance available to them at present.

$$
Y^{*}=\frac{1}{c} \Phi
$$

where $Y^{*}=$ production frontier (technical efficiency), $\frac{1}{c}$ is the reciprocal of the incremental capital output ratio (ICOR) given as $c=\frac{\Psi}{\varphi}$, where $\Psi$ is the annual investment in rice production and $\varphi$ represents annual increase in output of rice produced $\Phi=$ amount required to produce at the frontier level. The ICOR is hypothesized to be a measure of the inefficiency with which credit is used. The adapted $\mathrm{H}-\mathrm{D}$ model is thus hinged on the condition that the credit is used for the purpose of rice production. As posited by Bifarin et al. (2010), if production credit is invested on the farm, it is however, expected to lead to higher levels of output, but in case the credit is not accessed on time, it may, more often than not, lead to misapplication of funds. Hence, the expected impact of such funds will not be felt on the farm. If, however, the credit is invested in consumption purpose as peculiar to smallholder farmers, credit will likely not lead to an improvement in the efficiency level.

\subsection{Study area and source of data}

The study was carried out in the southwestern part of Nigeria consisting of the Lagos, Ogun, Oyo, Osun, Ondo and Ekiti States, collectively known as the South-West geographical zone of Nigeria. The area lies between the longitude $2^{\circ} 31^{1}$ and $6^{\circ} 00^{1} \mathrm{E}$ and the latitude $6^{\circ} 21^{1}$ and $8^{\circ} 37^{1} \mathrm{~N}$, with a total land area of about $77,818 \mathrm{~km}^{2}$. It is bounded in the east by the Edo and Delta States, in the north by Kwara and Kogi States, in the west by the Republic of Benin and in the south by the Gulf of Guinea. The climate of SouthWest Nigeria is tropical in nature and characterized by wet and dry seasons. The mean temperature ranges between 21 and $34{ }^{\circ} \mathrm{C}$, while the annual rainfall ranges between 150 and $3000 \mathrm{~mm}$. The wet season is associated with the southwestern monsoon wind from the Atlantic Ocean, while the dry season is associated with the northeastern trade wind from the Sahara Desert. The vegetation in South-West Nigeria is made up of fresh water swamp and mangrove forest at the belt, the low land in forest stretching inland to the Ogun and part of the Ondo states, with the secondary forest stretching towards the northern boundary by the derived and southern Guinea savannas (Agboola 1979). 
Table 1 Definitions and summary statistics of variables used in the model

\begin{tabular}{|c|c|c|c|}
\hline Variables & Description of variables & Mean & SD \\
\hline \multicolumn{4}{|l|}{ Efficiency model } \\
\hline Rice output & Quantity of rice produced in kg & $12,207.52$ & 5296.52 \\
\hline Insecticides & Quantity of insecticides applied per ha in litres & 2.16 & 1.87 \\
\hline Herbicides & Quantity of herbicides applied per ha in litres & 4.51 & 3.64 \\
\hline Seeds & Quantity of seeds sown per ha in $\mathrm{kg}$ & 27.45 & 5.22 \\
\hline Farm size & Farm size under rice production in ha & 2.95 & 1.22 \\
\hline Labour & Amount of hired and family labour in man-days & 79.92 & 24.54 \\
\hline \multicolumn{4}{|l|}{ Inefficiency model } \\
\hline Gender & 1 if $\mathrm{HH}$ head is male, 0 if female & 0.56 & 0.50 \\
\hline Age of the $\mathrm{HH}$ head & Age of HH head (years) & 47.28 & 7.67 \\
\hline Marital status & 1 if $\mathrm{HH}$ head is married, 0 if other/single/widowed & 0.80 & 0.40 \\
\hline Educational status & Years of education of HH head & 6.45 & 5.70 \\
\hline Household size & Number of $\mathrm{HH}$ size & 4.66 & 1.24 \\
\hline Off-farm income & $1=$ if $\mathrm{HH}$ engages in any off-farm activity & 0.54 & 0.50 \\
\hline Farming experience & Years of household experience in rice production & 15.73 & 5.09 \\
\hline Access to credit & 1 if $\mathrm{HH}$ has access to credit, 0 if otherwise & 0.57 & 0.50 \\
\hline Credit received & Amount of credit received (Naira) & $38,630.56$ & $47,577.03$ \\
\hline Farm size & Total land owned by $\mathrm{HH}$, in hectares & 7.37 & 3.04 \\
\hline Access to information & 1 if $\mathrm{HH}$ gets climate change information, 0 if otherwise & 0.36 & 0.48 \\
\hline Access to ext. contacts & 1 if $\mathrm{HH}$ has access to extension, 0 if otherwise & 0.53 & 0.50 \\
\hline Membership & 1 if $\mathrm{HH}$ belongs to Farmers' Association & 0.54 & 0.50 \\
\hline Location_Ekiti State & 1 if $\mathrm{HH}$ is from Ekiti, 0 if otherwise & 0.38 & 0.48 \\
\hline Location_Ondo State & 1 if $\mathrm{HH}$ is from Ondo, 0 if otherwise & 0.38 & 0.49 \\
\hline Location_Osun State & 1 if $\mathrm{HH}$ is from Osun, 0 if otherwise & 0.35 & 0.48 \\
\hline
\end{tabular}

A multistage sampling technique was used to select the respondents for the study from June to July, 2017. The first stage involved a typical case-purposive selection of three states, Ekiti, Ondo and Osun States located in the same agro-ecological area as shown in Fig 1. In the second stage, four local government areas (LGAs) were then selected from each state, based on the predominance of smallholder rice farmers in these areas, using a typical case-purposive sampling. In the third stage, five villages were randomly selected from each of the four LGAs. Following Tesfahunegn et al. (2016), at 95\% confidence level and 5\% margin of error, the sample size for the study was determined using the sample determination formula as described by Cochran (1977), allowing for six smallholder rice farmers to be selected from each of the 5 villages earlier selected to give 360 respondents interviewed for the study. Data were collected by means of a pre-tested, well-structured questionnaire by trained and experienced enumerators who have good knowledge of the farming systems and speak the local language in collaboration with the Agricultural Development Programme (ADP) agents in each state. Information sought were on respondents' socio-economic characteristics, inputs and output in rice production and as well as the costs of and returns on rice production. 


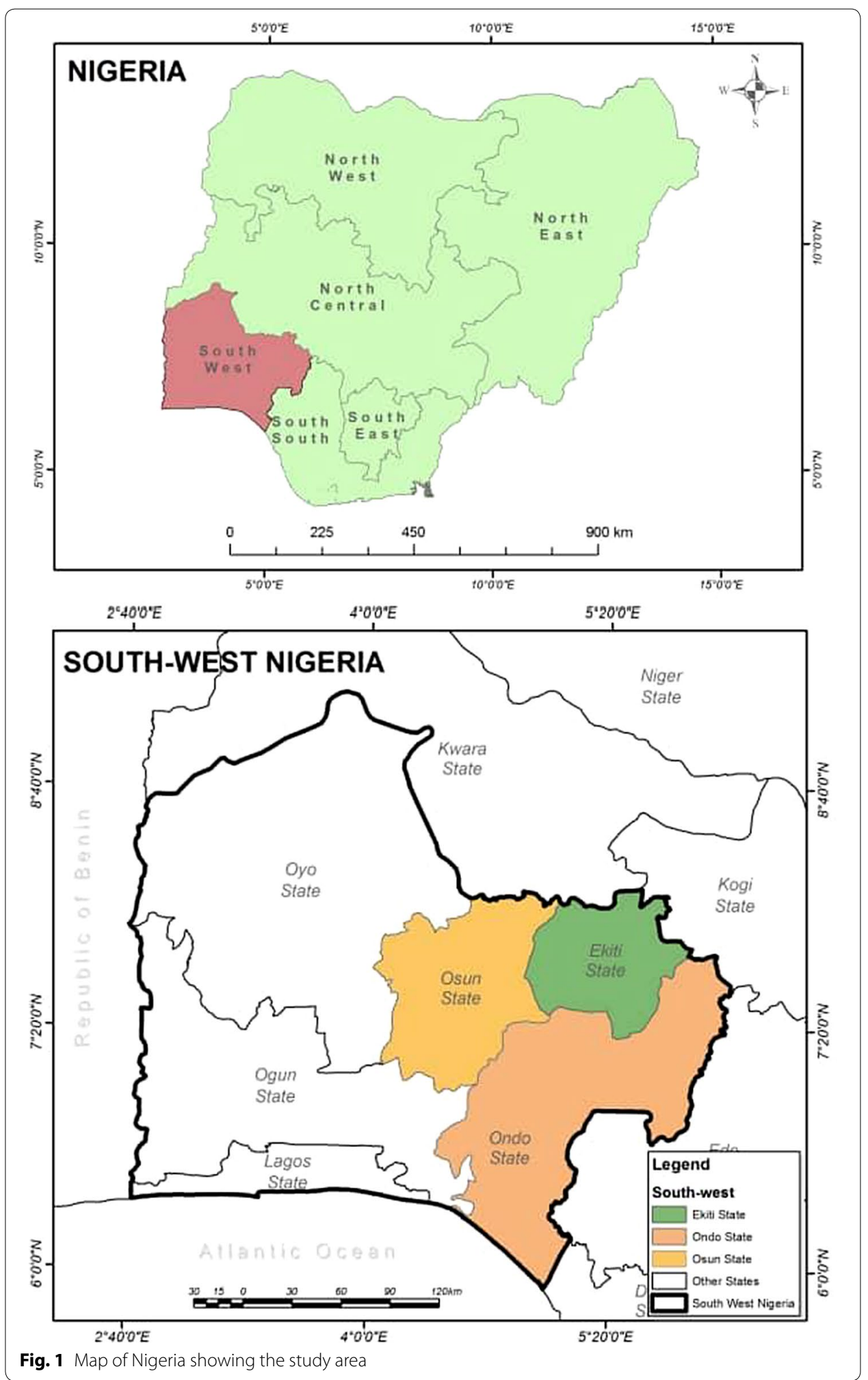




\section{Results and discussion}

The descriptive statistics of the surveyed rice farmers are presented in Table 1. The results show that $52 \%$ of the smallholder farmers adopted at least one climate change adaptation strategy in response to the changes in climatic conditions; and that the household heads' average age and years of education are 47 and 6 years, respectively. On extension access, about $53 \%$ of the respondents have contact with extension agents. About $57 \%$ of the rice smallholder farmers have access to credit, which is a major determinant in choosing adaptation strategies. However, there are clear variations in terms of access to information, for example, about $36 \%$ of the farmers who adopted at least one strategy have access to information related to credit. The average farming experience of the farmers in the study area is 15 years. The result is in agreement with Hitayezu et al. (2010), who posited that farmers' perception and efficient response to the economic conditions is directly related to their resource allocation ability, which is subsequently linked to their human capital endowment.

\subsection{Test for model specifications}

The result of the null hypothesis for the model is presented in Table 2. The null hypothesis of the frontier model was tested to ascertain the non-existence of technical inefficiency in the frontier of rice production in the study area. The null hypothesis was rejected as indicated by the $P$-value. This implies that the average response model does not fit the data well, as posited by the assumption of the stochastic frontier analysis model. As regards the functional form for the frontier model, Cobb-Douglas production function was chosen as the appropriate model as the model failed to reject the null hypothesis. The third null hypothesis test that none of the selected independent variables in the inefficiency effect model significantly explains farmers' technical inefficiency was also rejected in favour of the fact that at least one of the selected explanatory variables in the technical inefficiency model significantly explains the variation in farmers' technical inefficiency. Finally, the null hypothesis of homoscedasticity in both the stochastic and inefficiency variance of the error terms was not rejected, suggesting that the model is homoscedastic.

\subsection{The frontier estimates of the Cobb-Douglas stochastic frontier model}

The maximum likelihood estimates of the parameters of the Cobb-Douglas stochastic frontier production functions are presented in Table 3. As suggested by Coelli et al. (2005), it must be noted that their respective sample normalized all the output and inputs values means to enable us to explain the first-order coefficient as partial elasticities. All

Table 2 Test of null hypothesis

\begin{tabular}{lll}
\hline Hypothesis & $\boldsymbol{P}$-value & Decision rule \\
\hline Frontier test & $0.005^{* * *}$ & Frontier production appropriate \\
Inefficiency test & $0.000^{* * *}$ & Inefficiency effect present \\
Functional form test & 0.197 & Cobb-Douglas appropriate \\
Heteroscedasticity test & 0.8185 & Heteroscedasticity not present \\
\hline
\end{tabular}

*** represents significant level at $1 \%$ 


\begin{tabular}{|c|c|c|c|}
\hline LNOUTPUT & Coef. & Std. Err. & $P$-value \\
\hline Log of farm size & 0.400 & 0.402 & 0.921 \\
\hline Log of quantity of labour & 0.052 & 0.022 & $0.048^{* *}$ \\
\hline Log of herbicides & -0.045 & 0.020 & $0.088^{*}$ \\
\hline Log of volume of insecticides & 0.001 & 0.002 & 0.592 \\
\hline Log of quantity of seed & 0.171 & 0.091 & $0.060^{*}$ \\
\hline Constant & 1.399 & 0.400 & $0.000^{* * *}$ \\
\hline \multicolumn{4}{|l|}{ Inefficiency model } \\
\hline Age & 0.508 & 0.240 & $0.034^{* *}$ \\
\hline Gender & 5.156 & 2.813 & $0.067^{*}$ \\
\hline Farming experience & 3.476 & 1.270 & $0.006^{* * *}$ \\
\hline Household size & -11.636 & 4.784 & $0.015^{* *}$ \\
\hline Access to credit & -18.609 & 10.956 & $0.089^{*}$ \\
\hline Access to information & -13.231 & 6.033 & $0.028^{* *}$ \\
\hline Membership in cooperative & 4.652 & 3.208 & 0.147 \\
\hline Access to improved variety & -19.919 & 6.951 & $0.004^{* * *}$ \\
\hline Location_Osun & -15.420 & 5.932 & $0.009^{* * *}$ \\
\hline Location_Ondo & -20.535 & 8.033 & $0.011^{* *}$ \\
\hline Constants & -73.968 & 27.088 & $0.006^{* * *}$ \\
\hline$\delta^{2}$ & -4.558 & 0.075 & $0.000^{* * *}$ \\
\hline Prob $>\mathrm{Chi}^{2}$ & & & $0.0842^{*}$ \\
\hline Log likelihood & 306.07221 & & \\
\hline Wald $\mathrm{Chi}^{2}(5)$ & 9.70 & & \\
\hline Mean efficiency score & 70 & & \\
\hline
\end{tabular}

estimated coefficients in the Cobb-Douglas model fall between zero and one, satisfying the monotonicity condition that all marginal products are positive and diminishing at the mean of inputs. These results are consistent with the estimates of Abdulai and Abdulahi (2016) who also found positive and significant effects of frontier variables on output of maize farmers in Zambia. The average technical efficiency of $70 \%$ suggests that an average smallholder rice farm in the sample requires about $30 \%$ additional resources to get to the frontier. In other words, a smallholder rice farmer lost an average of $30 \%$ of output due to technical inefficiency.

The sum of first-order estimates of the production inputs which are referred to as the scale elasticity reveals decreasing returns to scale in the frontier model sum up to 0.57 suggesting that an average farm from the study area experiences a decreasing return-to-scale. The implication of the results shows that increasing all inputs by a certain proportion would result in a less than proportionate increase in output of the smallholder rice farmers in Nigeria. This could be attributed to the fact that scale inefficiency among farmers in developing countries, estimates of decreasing returns to scale seem consistent with expectation as agricultural production commonly exhibits decreasing returns to scale (Abdul-Rahaman 2016; Khanal et al. 2018).

The coefficient of labour as measured in man-day is positive and statistically significant in increasing the rice output. In line with Hazell et al. (2007), labour intensification 
in the agricultural sector improves growth in the rural economy. The implication of the result shows that rice output increases as the quantity of labour is increases. The plausible implication of the significance of labour for rice output is not unexpected since smallholder farmers rely heavily on manual labour with farming operations in developing countries such as Nigeria are resource-constrained. This finding is in line with the study conducted by Mensah and Brummer (2016) who reported an increasing effect of labour supply on the output of mango producers in some selected regions in Ghana. Huy and Nguyen (2019) also found an increasing effect of labour in their study on cropland rental market and farm technical efficiency in rural Vietnam.

Weeds remain a major challenge to increasing crop output as they compete with the crop plants for nutrients and water among others. The coefficient of herbicides is negative and statistically significant in reducing the productivity of a rice in the study area. The negative and significant coefficient of the value of herbicides indicates an inverted U-shaped response function. The implication of the results shows that a continuous increase in the quantity of herbicides while the value would at a point decrease rice yield. This indicates that, after a certain point in the production process, a higher quantity of herbicides is not beneficial in increasing rice productivity. Another plausible explanation could be over-application, inappropriate use or application of unapproved herbicides which subsequently increases input cost that reduces expenditures on other inputs without positive contribution to the productivity of rice (Danso-Abbeam and Baiyegunhi 2017). This stage of negative contribution of herbicides to the productivity of rice production is marked as the irrational stage (stage III) of production.

The coefficient of quantity of seed planted was positive and statistically significant in increasing the efficiency of rice production in the study area. This implies that as the quantity of rice planted increases by $1 \%$, the output of rice increases by $17 \%$. This result corroborates the study of Ogundari (2008) who also found an increasing effect of quantity of rice planted on rice output in his study on the resource-productivity, allocative efficiency and determinants of technical inefficiency of rainfed rice farmers in Nigeria.

\subsection{Determinants of technical inefficiency in rice production}

\subsubsection{Household characteristics}

The results show that the age of the rice farmer exerts a positive significant effect on inefficiency of rice farming in Nigeria. This implies that as the age of smallholder rice farmers increases, the level of inefficiency also increases. This is expected as relatively, the positive sign for age indicates that older farmers are less efficient as against the young farmers who energetic and would also want to take risk of trying innovation in farming practices which may increase their production efficiency (Alwarritzi et al. 2015). This finding is in line with the study of Villano and Flemming (2006), suggesting that selfsatisfaction among relatively old farmers has the propensity to decrease their probability of adopting new farming practices, therefore, lowering their productive efficiency level.

The coefficient of gender shows a positive sign and statistically significant at $10 \%$. This result implies that male farmers tend to be less efficient compared to their female counterparts. This is in line with the study of Kinkingninhoun-Me^dagbe' et al. (2010) who 
estimated technical efficiency indices between men and women and the result of the study shows that women are on average more technically efficient than men.

Further, the number of years of experience in rice production was expected to reduce technical inefficiency. Result of this study shows that farming experience positive and statistically significant in increasing the technical inefficiency of smallholder rice farmers in the study area. This could be attributed to the conventional nature of some experienced farmers. Some farmers are so satisfied with their rudimentary method of farming such that they find it difficult to switch to new farming practices, hence, reduce productive efficiency. This finding is in consonance with Danso-Abbeam and Baiyegunhi (2017) who also found a negative relationship between farming experience and technical efficiency among cocoa farmers in Brong-Ahafo region of Ghana. Conversely, Khanal et al. (2018) suggested that the more experienced household heads can better manage agricultural activities and adapt to new farming practices than less experienced ones, thereby increasing the technical efficiency of agricultural production.

The result of this study shows that the estimate of household size is negatively signed and statistically significant in reducing the smallholder rice farmers' inefficiencies. This implies that the technical inefficiency of the respondents decreases as the household size increases. The plausible explanation for this could be attributed to the ability of the household to supply surplus family labour as argued by Gautam and Andersen (2016). As posited by Ahmed and Melesse (2018), household size is an indicator of labour availability as measured in terms of adult equivalent. A large family size implies the availability of labour by a family who can actively engage in farming activities and facilitate the adoption of adaptation measures against climate change effects (Uddin et al. 2014) which ultimately increases the technical efficiency of rice production among rice farmers in South-west, Nigeria.

\subsubsection{Institutional factors}

According to Alfred and Xiao (2013) and supported by Quaye et al. (2014), supply and access to capital are critical to improving agricultural production and economic growth. As posited by the International Finance Corporation (IFC), about $84 \%$ of small and medium-sized enterprises (SMEs) including smallholder farmers in Africa are either un-served or underserved, representing a financial gap of USD 140-170 billion. Easing potential credit constraints through the timely granting of credit reduces the opportunity costs of some capital-intensive climate change adaptation strategies (Binam et al. 2004). A negative and statistically significant relationship found between access to credit and technical inefficiency implies that overcoming credit constraints is likely to enhance the productive efficiency of smallholder rice farmers in South-west, Nigeria. The significant coefficient for credit indicates that access to enough and timely credit is a significant factor in bridging the financing gap and ultimately improves agricultural productivity. These results are in agreement with the findings of Chandio et al. (2017) who posited that institutional credit facilitates and increases the productivity of the farmers. It is also in line with the findings of Bozoglu and Ceyhan (2007) who posited that credit use increased technical efficiency among vegetable farmers in Samsun province, Turkey.

As argued by Abdulai and Abdulai (2016), visits by extension agents to the famers were used to account for access to information from institutional sources. Access to extension 
is expected to improve famers' level of exposure to information on farm practices and farm inputs. Access to extension is measured as whether farmer had contact with an extension agent on the production methods within the past three production seasons. The coefficient of access to information is negative and statistically significant in reducing inefficiency of rice production. This implies that access to information from extension agents and other sources of information improves the efficiency of rice production in Nigeria. This is in consonance with the study of Donkor et al. (2018) in their study on efficiency of rice production in Ghana concluded that if agricultural innovation systems is incorporated by the policymakers to facilitate the dissemination of knowledge from researchers to extension agents and then to the agricultural producers, rice production efficiency will be improved.

Access to information about agricultural related activities would improve the productivity of farmers (Khanal et al. 2018). The variable representing access to climate change information is negative and statistically significant with inefficiency in rice production. This implies that farmers with better access to information are more efficient as compared with others with inadequate access to information. The smallholder rice farmers with better access to agricultural information were more progressive and therefore exhibited greater efficiency. The coefficient of use of improved seeds was negatively signed and statistically significant with the smallholder rice farmers' inefficiency in rice production. This is in agreement with the findings of Bhatt and Bhat (2014) and Dessale et al. (2017) who found a positive relationship between improved planting varieties and technical efficiency. It means that the tendency for any smallholder rice farmers to increase his/her production depends on the type and quality of improved seed available at the right time of planting.

\subsubsection{Location variables}

The location dummies are included to capture managerial and environmental differences among farms located in different states (Danso-Abbeam and Baiyegunhi 2017). Location variable is expected to have an impact on technical efficiency of rice farmers in the South-west, Nigeria. It is assumed that farmers located in the same region apply similar managerial techniques due to their proximity and are have a similar physical environment, soil quality. The coefficients for the district dummies for the farmers located in Osun and Ondo States are negatively signed and statistically significant in reducing inefficiency in rice production. The negative sign indicates that smallholder rice farmers located in both Osun and Ondo exhibit higher efficiencies in rice production. This is in consonance with the study of Otitoju and Enete (2014) on climate change adaptation strategies and farm-level efficiency in food crop production in Southwestern, Nigeria.

\subsection{Financing gap estimation}

Access to finance is often seen as one of the major impediments in agricultural production disproportionately (Ayyagari et al. 2012), and lack of data has made it very difficult to determine the exact size of the financing gap (Peer et al. 2013). This lack of access to credit from the traditional financial sector is alarming in a situation where the poor represent the largest share of the population in many African countries and that 
the informal sector represents an integral part of the economy in these countries. A large number and variety of microfinance institutions have been established in recent years in Africa to serve the unsatisfied demand for financial services-particularly in the informal sector. Following Ayanwale et al. (2018), to estimate the financing gap experienced by smallholder rice farmers, a target production increase for each rice producer was set through the technical efficiency of the farmer first determined using the stochastic frontier function. Thereafter, the current efficiency of the farmer, the corresponding quantity of rice produced at the current efficiency and the target efficiency or expected increase in efficiency due to credit availability were used to estimate the quantity of rice expected to be produced at the target efficiency which is the frontier efficiency in this study area. The difference in rice quantity at the current efficiency and that at the target efficiency is then taken as the desired increase in production due to finance availability. Using an adapted version of Harrod-Domar (HD), the financial amount required to produce at the target efficiency was estimated.

Thereafter, the amount currently being used by the farmers is subtracted from the estimated finance at the target efficiency and the difference is taken as the financing gap of each farmer. This represents the external financing (in form of credit) that would be required by smallholder rice farmer. In doing this, it is assumed that: (1) majority of the rice producers were not producing at the frontier level and that the immediate concern was to provide finance in form of credit that will impact positively on their technical efficiencies to cause increase in production at a higher efficiency level (frontier level) compared to the present situation. (2) Credit amount required by each smallholder rice farmer to attain the technical efficiency at the frontier level is proportional to the production frontier (technical efficiency) by a constant known as the Incremental Capital Output Ratio (ICOR). (3) Credit (finance) requirement of each smallholder rice farmer is given by the gap between the credit amount required to produce at the frontier level and the finance used to produce at their present level of efficiency.

As shown in Fig. 2, the estimated financing gap of smallholder rice farmers in the study area. The table reveals that $13.33 \%$ of the respondents have financing gap of not more than $\$ 100,000$. Also, about $40 \%$ of the farmers experienced financing gap of not more than 200,000 while about $36 \%$ experienced financing gap of not more than $\$ 300,000$. This implies that two-thirds $(76 \%)$ of the smallholder rice farmers would require an amount between $\$ 200,000$ and $\$ 300,000$ to produce at the frontier level. In addition, the table showed that to produce at the frontier level, only about $10 \%$ would require an amount greater than 400,000 . This suggests that majority (76\%) as revealed in Table 4 of the smallholder rice farmers would require not less than or equal to 250,000 to fill the financing gap being presently experienced and be able to produce at the frontier level with other necessary conditions for production being in place. As further revealed in Table 4, the mean credit amount per season that farmers had access to was, $38,630.56$ while the mean financing in the form of credit required to produce at the frontier level was $193,626.50$, showing a financing shortfall of about $80 \%$. The implication of these results as posited by Ojo et al. (2019) show that to improve the productivity of rice farmers, government and development partners should work together to improve the conditions of access of rice farmers to suitable agricultural credit, including the policy incentives aimed at lowering the cost of borrowing in the Nigerian agricultural sector. 


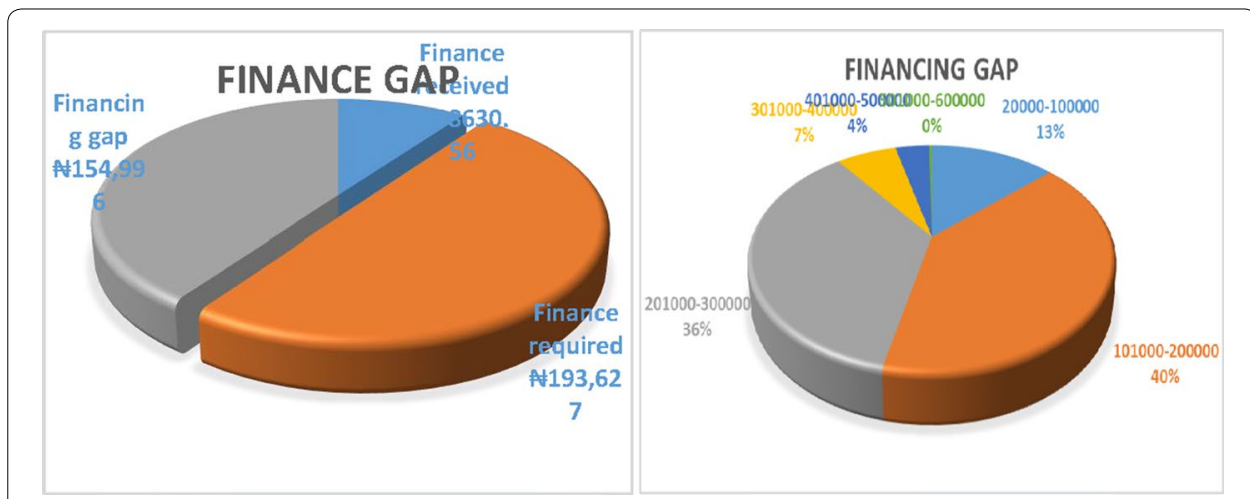

Fig. 2 Financing gap analysis

Table 4 Financing gap analysis

\begin{tabular}{lcl}
\hline Financing gap $\left(\mathrm{(N}^{\mathbf{1}}\right)$ & Frequency & Percentage \\
\hline $20,000-100,000$ & 48 & 13.33 \\
$101,000-200,000$ & 145 & 40.28 \\
$201,000-300,000$ & 130 & 36.11 \\
$301,000-400,000$ & 23 & 6.39 \\
$401,000-500,000$ & 13 & 3.61 \\
$501,000-600,000$ & 1 & 0.28 \\
Total & 360 & 100 \\
\hline Variables & Mean & Standard deviation \\
\hline Credit amount received & $38,630.56$ & $47,577.03$ \\
Credit amount required (financing gap) & $193,626.5$ & $100,944.7$ \\
\hline
\end{tabular}

$1 \$ 1$ is equivalent to 365

\section{Conclusion and policy recommendations}

This study primarily focuses on assessing the financing gaps relative to production frontier of smallholder rice farmers in Southwestern Nigeria. It also investigates the sociodemographic factors that influence inefficiency in agricultural production among rice farmers. As a caveat for this study, the technical efficiency of rice smallholder rice farmers is estimated and an adapted form of the Harold-Domar (HD) growth model was employed to estimate the financing (credit) gap of smallholder rice farmers in Southwestern Nigeria. However, age, gender, farming experience, household size, access to credit, access to information, adoption of improved variety and location of rice farmers as sources of technical inefficiencies. As revealed by the result of the HD growth model, the average amount of credit per season that farmers had access to was, \#38,630.56 while the mean financing in the form of credit required to produce at the frontier level was 193,626.50, showing a financing shortfall of about $80 \%$. As unravelled by the result of the study, it can thus be concluded that technical efficiency of rice farmers can be improved by ameliorating access to timely credit and agricultural information for improving rice productivity. The growth of smallholder farmers is usually hampered by limited access to credit especially by banks despite their significant 
contributions to economic development. These findings suggest that filling the financing gap of smallholder rice farmers will improve rice productivity in Nigeria. The study, therefore, recommends that in order to improve rice production efficiency to meet the geometric increase in demand, location-specific policy interventions are necessary to improve the efficiency of rice production in Nigeria. The potential gains intrinsic in the current domestic rice cultivation, processing, and consumption policy makes it critical that the current federal administration retain and sustain the policy. Agricultural innovation systems perceptions should be incorporated by the policymakers to facilitate the dissemination of knowledge from researchers and academics, to extension agents and then to the agricultural producers. A necessary addition should be developed to the assistance already being provided under Nigeria Incentive-Based Risk Sharing System for Agricultural Lending (NIRSAL) in the form of loan guarantees and other risk-sharing incentives, such as a regulatory environment that supports the modern contractual obligations that are characteristic of well-functioning agricultural financing. This would not only bridge the financing gap, but also improve the intensification of rice production in Nigeria to meet its increasing rice demand, and also improve rice farmers' productivity and their households' incomes. The transformation of the agricultural finance system will also involve upgrading farmers' risk management capacity in terms of prevention, mitigation, and adaptation strategies.

\section{Acknowledgements}

We are very grateful to the enumerators and the farmers who sat patiently for hours providing responses to the questionnaire.

\section{Authors' contributions}

TOO application of statistical, mathematical, computational, or other formal techniques to analyze or synthesize study data; AAO formulation or evolution of overarching research goals and aims. He designed the methodology and identification of models; SCB responsible for oversight and leadership responsibility for the research activity planning and execution, including mentorship external to the core team; TA responsible for oversight and leadership responsibility forthe research activity planning and preparation and formatting of the manuscript. All authors read and approved the final manuscript

Funding

This research did not receive any specific grant from funding agencies in the public, commercial, or not-for-profit sectors.

Availability of data and materials

The data that support the findings of this study can be obtained from the authors upon request.

Ethics approval and consent to participate

Ethical approval and consent to participate are not applicable for this study.

Competing interests

The authors declare that they have no competing interests.

\section{Author details}

1 Disaster Management Training and Education Centre for Africa, University of the Free State, Bloemfontein, South Africa. ${ }^{2}$ Department of Agricultural Economics, University of the Free State, Bloemfontein, South Africa. ${ }^{3}$ International Food Policy Research Institute, Washington, DC, USA. ${ }^{4}$ Department of Agricultural Economics, Obafemi Awolowo University, lle-Ife, Nigeria.

Received: 9 October 2019 Revised: 26 November 2019 Accepted: 22 January 2020

Published online: 10 February 2020

\section{References}

Abdulai AN, Abdulai A (2016) Allocative and scale efficiency among maize farmers in Zambia: a zero efficiency stochastic frontier approach. Appl Econ 48(55):5364-5378. https://doi.org/10.1080/00036846.2016.1176120

Abdul-Rahaman A (2016) Stochastic frontier analysis (SFA) of technical efficiency, insights from smallholder cotton farmers in the Northern Region of Ghana. Glob J Agric Econ Ext Rural Dev 4(1):361-367

Agboola SA (1979) An agricultural atlas of Nigeria. An agricultural atlas of Nigeria. Oxford University Press, Oxford 
Ahmed MH, Melesse KA (2018) Impact of off-farm activities on technical efficiency: evidence from maize producers of eastern Ethiopia. Agric Food Econ 6(1):3-13

Aigner D, Lovell CK, Schmidt P (1977) Formulation and estimation of stochastic frontier production function models. J Econometr 6(1):21-37

Akinbode SO (2013) Access to credit: implication for sustainable rice production in Nigeria. J Sustain Dev Africa 15(1):13-30

Alfred S, Xiao W (2013) Financing Family Business in Ghana, Challenges and the way forward. Int J Adv Res Manage Soc Sci 2(2):177-204

Alwarritzi W, Nanseki T, Chomei Y (2015) Analysis of the factors influencing the technical efficiency among oil palm smallholder farmers in Indonesia. Procedia Environ Sci 28:630-638

Awotide BA, Karimov A, Diagne A, Nakelse T (2013) The impact of seed vouchers on poverty reduction among smallholder rice farmers in Nigeria. Agric Econ 44(6):647-658

Ayanwale AB, Fatunbi AO, Ojo MP (2018) Baseline Analysis of Plantain (Musa sp.) Value Chain in Southwest of Nigeria, vol 3, No. 1. FARA Research Report, $\mathrm{p} 84$

Ayyagari M, Demirgüç-Kunt A, Maksimovic V (2012) Financing of Firms in developing countries: lessons from research. Policy research working paper 6036, World Bank, Washington DC

Battese GE, Coelli TJ (1995) A model for technical inefficiency effects in a stochastic frontier production function for panel data. Empir Econ 20(2):325-332

Bermejo Carbonell J, Werner RA (2018) Does foreign direct investment generate economic growth? A new empirical approach applied to Spain. Econ Geogr 94(4):425-456

Bhatt MS, Bhat SA (2014) Technical efficiency and farm size productivity — micro level evidence from Jammu \& Kashmir. Int J Food Agric Econ (IJFAEC), 2(1128-2016-92057), p 27

Bifarin JO, Alimi T, Baruwa Ol, Ajewole OC (2010) Determinant of technical, allocative and economic efficiencies in the plantain (Musa spp.) production industry, Ondo State, Nigeria. In: Proceeding of international conference on banana \& plantain in Africa, Edited by Dubois T, et al. Acta Hort 879:199-210

Binam JN, Tonye J, Nyambi G, Akoa M (2004) Factors affecting the technical efficiency among smallholder farmers in the slash and burn agriculture zone of Cameroon. Food Policy 29(5):531-545

Bozoğlu M, Ceyhan V (2007) Measuring the technical efficiency and exploring the inefficiency determinants of vegetable farms in Samsun province, Turkey. Agric Syst 94(3):649-656

Caudill SB, Ford JM (1993) Biases in frontier estimation due to heteroscedasticity. Econ Lett 41(1):17-20

Coelli Tim J (1995) Recent development in frontier modelling and efficiency measurement. Aust J Agric Econ 39(3):219-245

Coelli TJ, Rao DSP, O'Donnell CJ, Battese GE (2005) An introduction to efficiency and productivity analysis. Springer Science \& Business Media

Chandio AA, Jiang Y, Gessesse AT, Dunya R (2017) The nexus of agricultural credit, farm size and technical efficiency in Sindh, Pakistan: a stochastic production frontier approach. J Saudi Soc Agric Sci. https://doi.org/10.1016/j.jssas 2017.11.001

Chenery HB, Strout AM (1966) Foreign assistance and economic development. Am Econ Rev 56(4):679-733

Cochran WG (1977) Sampling techniques, 3rd edn. John Wiley \& Sons, New York

Danso-Abbeam G, Baiyegunhi LJ (2017) Adoption of agrochemical management practices among smallholder cocoa farmers in Ghana. Afr J Sci Technol Innov Dev 9(6):717-728

Dessale M, Beshir D, Tegegne D (2017) Technical efficiency in teff production: the case of smallholder farmers in Jamma District, South Wollo Zone, Ethiopia (Doctoral dissertation, Haramaya University)

Donkor E, Matthews N, Ogundeji AA (2018) Efficiency of rice farming in Ghana: policy implications for rice sector development. Afr Dev Rev 30(2):149-161

Easterly W (1999) The ghost of financing gap: testing the growth model used in the international financial institutions. Dev Econ 60(2):423-438

FAO (2015) Regional overview of food insecurity in Africa African food security: prospects brighter than ever. Food and Agriculture Organization. http://www.fao.org/3/a-i4635e.pdf. Accessed 4 Feb 2016

Fakayode SB, Rahji MAY, Oni OA, Adeyemi MO (2009) An assessment of food security situations of farm households in Nigeria: a USDA approach. Soc Sci 4(1):24-29

Gautam Y, Andersen P (2016) Rural livelihood diversification and household well-being: insights from Humla, Nepal. J Rural Stud 44:239-249

Geda A, Shimeles A, Weeks J (2009) Growth, poverty and inequality in Ethiopia: which way for pro-poor growth? J Int Dev J Dev Stud Assoc 21(7):947-970

Goni M, Mohammed S, Baba BA (2007) Analysis of resource-use efficiency in rice production in the Lake Chad area of Borno State, Nigeria. J Sustain Dev Agric Environ 3(2):31-37

Guirkinger C, Boucher SR (2008) Credit constraints and productivity in Peruvian agriculture. Agric Econ 39(3):295-308

Hazell PB, Poulton C, Wiggins S, Dorward A (2007) The future of small farms for poverty reduction and growth, vol 42. International Food Policy Research Institute, Washington

Hitayezu P, Okello JJ, Gor CO (2010) Drivers of household participation in the rural non-farm labor markets in the postwar Rwanda (No. 320-2016-10088)

Hussain MA (2000) Convergence of per capita output levels across regions of Bangladesh, 1982-97 (No. 0-121). International Monetary Fund

Huy HT, Nguyen TT (2019) Cropland rental market and farm technical efficiency in rural Vietnam. Land Use Policy 81:408-423

Kenmore P (2003) Sustainable rice production, food security and enhanced livelihoods. Rice Science, Innovations and Impact for Livelihoods. International Rice Research Institute, Los Banos, pp 27-34

Khanal U, Wilson C, Shankar S, Hoang VN, Lee B (2018) Farm performance analysis: technical efficiencies and technology gaps of Nepalese farmers in different agro-ecological regions. Land Use Policy 76:645-653 
Kinkingninhoun-Me^dagbe FM, Diagne A, Simtowe F, Agboh-Noameshie AR, Adegbola PY (2010) Gender discrimination and its impact on income, productivity, and technical efficiency: evidence from Benin. Agric Hum Values 27:57-69 Kumbhakar S, Lovell CAK (2000) Stochastic frontier analysis. Cambridge University Press, Cambridge

Lu HP, Luo T, Fu HW, Wang L, Tan YY, Huang JZ et al (2018) Resistance of rice to insect pests mediated by suppression of serotonin biosynthesis. Nat Plants 4(6):338

Mensah A, Brummer B (2016) Drivers of technical efficiency and technology gaps in Ghana's mango production sector: a stochastic metafrontier approach Amos. Afr J Agric Resour Econ 11(311-2016-5651), 101

Mohanty S, Wassmann R, Nelson A, Moya P, Jagadish SVK (2013) Rice and climate change: significance for food security and vulnerability. International Rice Research Institute, Los Baños, p 14

Obih U, Baiyegunhi $\sqcup$ (2017) Implicit price estimation of quality attributes influencing rice prices and choice decisions of consumers in Nigeria. J Agribus Rural Dev 3(45):639-653

Obih U, Baiyegunhi L (2018) Consumers' acceptability of local rice brands in Nigeria. Which marketing functions really matter? J Agribus Rural Dev 2(48):183-196

Ogundari K (2008) Resource-productivity, allocative efficiency and determinants of technical efficiency of rainfed rice farmers: a guide for food security policy in Nigeria. Agric Econ Czech 54(5):224-233

Ogundele OO, Okoruwa VO (2006) Technical efficiency differentials in rice production technologies in Nigeria. AERC Research Paper 154. African Economic Research Consortium, Nairobi

Ojo TO, Baiyegunhi LJS, Salami AO (2019) Impact of credit demand on the productivity of rice farmers in South West Nigeria. J Econ Behav Stud 11(1):166-180

Olomola A, Gyimah-Brempong K (2014) Loan Demand and Rationing among Small-Scale Farmers in Nigeria. Discussion Paper Series 01403. Washington, DC: International Food Policy Research Institute (IFPRI)

Otitoju MA, Enete AA (2014) Climate change adaptation strategies and farm-level efficiency in food crop production in Southwestern. Nigeria. Tropicultura 32(3):113-120

Peer S, Oya PA, Martin H (2013) Closing the credit gap for formal and informal micro, small, and medium enterprises. International Finance Corporation, World Bank Group, Washington DC

Quaye I, Abrokwah E, Sarbah A, Osei JY (2014) Bridging the SME financing gap in Ghana: the role of microfinance institutions. Open J Bus Manag 2(04):339

Tang VT, Shaw TM, Holden MG (eds) (2018) Development and sustainable growth of mauritius. Springer, Berlin

Tesfahunegn GB, Mekonen K, Tekle A (2016) Farmers' perception on causes, indicators and determinants of climate change in northern Ethiopia: implication for developing adaptation strategies. Appl Geogr 73:1-12

Uddin M, Bokelmann W, Entsminger J (2014) Factors affecting farmers'adaptation strategies to environmental degradation and climate change effects: a farm level study in Bangladesh. Climate 2(4):223-241

USDA (United States Department of Agriculture) (2016) Production, supply and distribution. Washington, DC: United States Department of Agriculture. http://apps.fas.usda.gov/psdonline/psdquery.aspx

van der Merwe J, Dodd N (2019) Different schools, same problems: development theory in the twentieth century. In the political economy of underdevelopment in the global South. Palgrave Macmillan, Cham, pp 17-33

Villano R, Fleming E (2006) Technical inefficiency and production risk in rice farming: evidence from central Luzon Philippines. Asian Econ J 20:29-46

\section{Publisher's Note}

Springer Nature remains neutral with regard to jurisdictional claims in published maps and institutional affiliations.

\section{Submit your manuscript to a SpringerOpen ${ }^{\circ}$ journal and benefit from:}

- Convenient online submission

- Rigorous peer review

- Open access: articles freely available online

High visibility within the field

Retaining the copyright to your article

Submit your next manuscript at $\boldsymbol{s p r i n g e r o p e n . c o m ~}$ 